\title{
Distribution, status, social organisation, movements and conservation of Baudin's Cockatoo (Calyptorhynchus baudinii) in South-west Western Australia
}

\author{
R.E. Johnstone' ${ }^{1}$ and T. Kirkby ${ }^{2}$ \\ Department of Terrestial Zoology, Western Australian Museum, Locked Bag 49, \\ Welshpool DC, Western Australia 6986, Australia. \\ 49 Canning Mills Road, Kelmscott, Western Australia 6111, Australia.
}

\begin{abstract}
Baudin's Cockatoo (Calyptorhynchus baudinii) is a large, iconic, forest cockatoo, endemic to the south-west corner of Western Australia and currently listed as endangered. It has suffered a substantial decline in numbers in the past 50 years. Direct causes of population decline include large numbers shot by orchardists, fragmentation of habitat and the impact of hollow competitors. In this paper we provide details of distribution, status, habitat preferences, breeding, social organisation, migration and movements, roost sites and diet. We also include observations on the relationships between birds at two large autumn-winter roost sites, eight kilometres apart in the Perth hills. The conservation of this cockatoo provides a challenge for the future especially in reducing its major threats. We recommend future monitoring of major roosts in order to determine population trends and to measure progress in conservation efforts.
\end{abstract}

\section{INTRODUCTION}

Two species of white-tailed black cockatoo Baudin's Cockatoo (Calyptorhynchus baudinii Lear, 1832) and Carnaby's Cockatoo (C. latirostris Carnaby, 1948) - are endemic to the south-west of Western Australia (Johnstone and Storr 1998). They form a very distinctive part of the avifauna, with their conspicuous, often large flocks and raucous behaviour.

The two species can be extremely difficult to separate, even for experienced observers, and were only recognised as separate species in 1979 (Saunders 1979). Bill size and shape and calls are the most reliable means of identification. Baudin's Cockatoo has the bill or culmen more laterally compressed than in Carnaby's with the upper mandible significantly longer and finer (i.e. with the tip tapering well beyond the lower mandible when closed) (Campbell and Saunders 1976) (Figure 1). Baudin's Cockatoo also has a much shorter "whicha-whicha" contact call compared to the longer "wee-looo wee-looo" of Carnaby's. Due to the great similarity between the two species many of the historical observational records and indeed even much of the recent literature is misleading because of the high degree of error in identifying the two species.

Both species have suffered a substantial decline in numbers and breeding distribution in the past 50 years (Johnstone and Storr 1998). The ability of both species to exploit resources provided by humans, especially in apple, pear, persimmon and nut orchards and pine plantations, and their habit of forming large feeding flocks, has in the past brought them into conflict with orchardists and foresters (Long 1985; Chapman 2007). Direct causes of population decline include the large numbers shot by orchardists (mainly with Baudin's Cockatoo), clearing and fragmentation of habitat (especially the loss of breeding hollows) and the impact of hollow competitors including the Galah (Cacatua roseicapilla), corellas including Butler's Corella (Cacatua pastinator butleri), Australian Shelduck (Tadorna tadornoides), Australian Wood Duck (Chenonetta jubata), the feral European honey bee (Apis mellifera) and also vehicle strikes. Illegal shooting of Baudin's Cockatoos still continues in parts of the south-west (DEC 2008) and with its low reproduction rate $(0.6$ chick per year or every two years) this cockatoo can not replace large numbers shot by orchardists. Around $90 \%$ of the original vegetation in the south-west region has been cleared for agriculture (crops), meat production, dairying, orchards, vineyards, pine plantations, mining, wood chipping, cities and towns. At present extensive tracts of uncleared land only remain in forest reserves and nature reserves and what is left of remnant vegetation (e.g. in roadside verges) is often disturbed. The south-west region is now a severely fragmented landscape and the further loss of foraging habitat, the lack of suitable breeding sites, climate change and competition with 


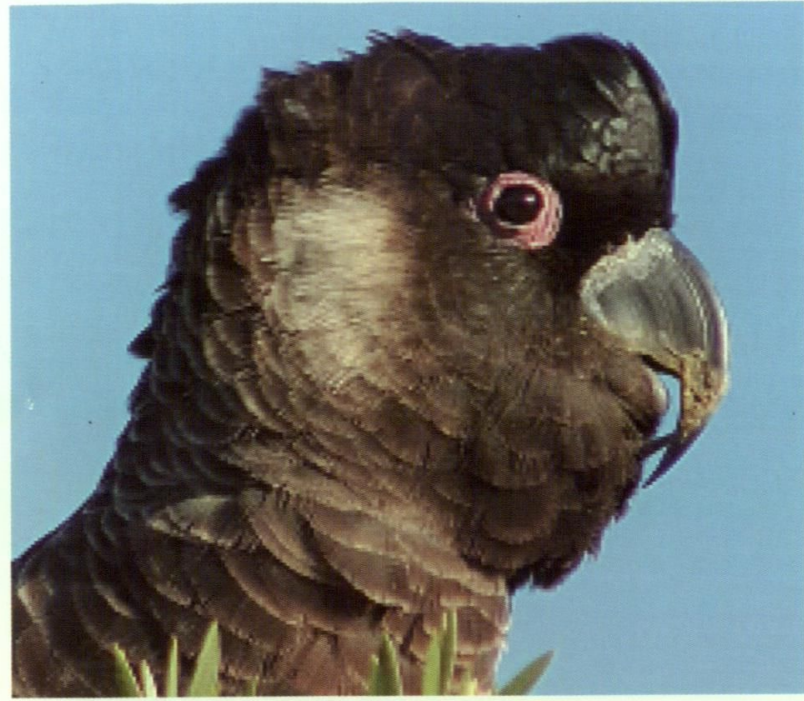

Male Baudin's Cockatoo

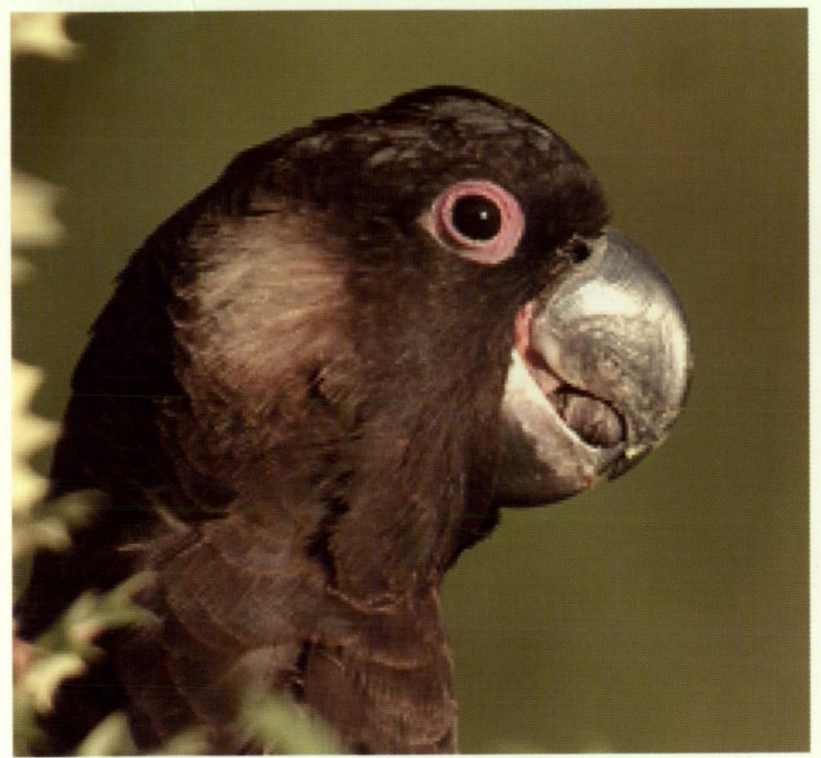

Male Carnaby's Cockatoo

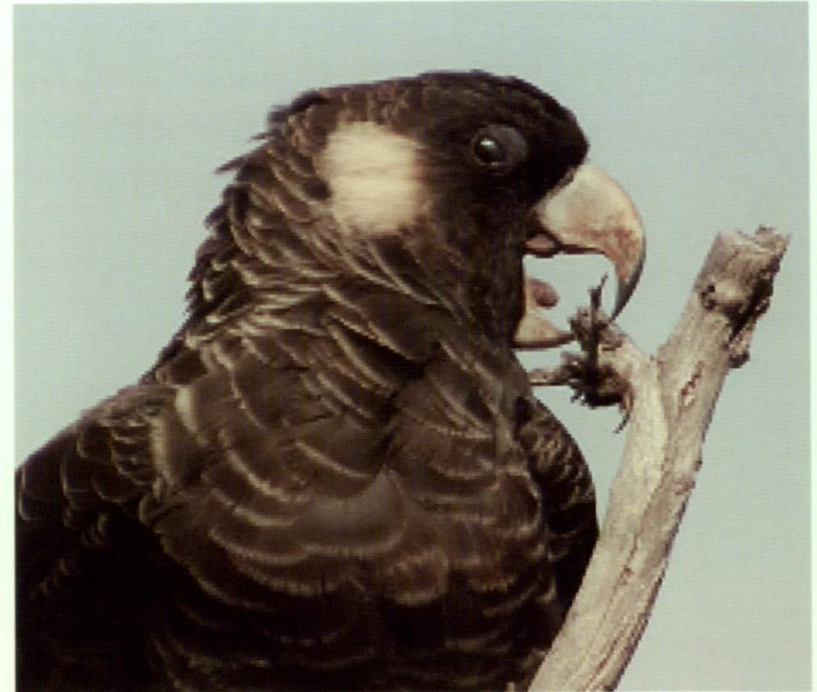

Female Baudin's Cockatoo

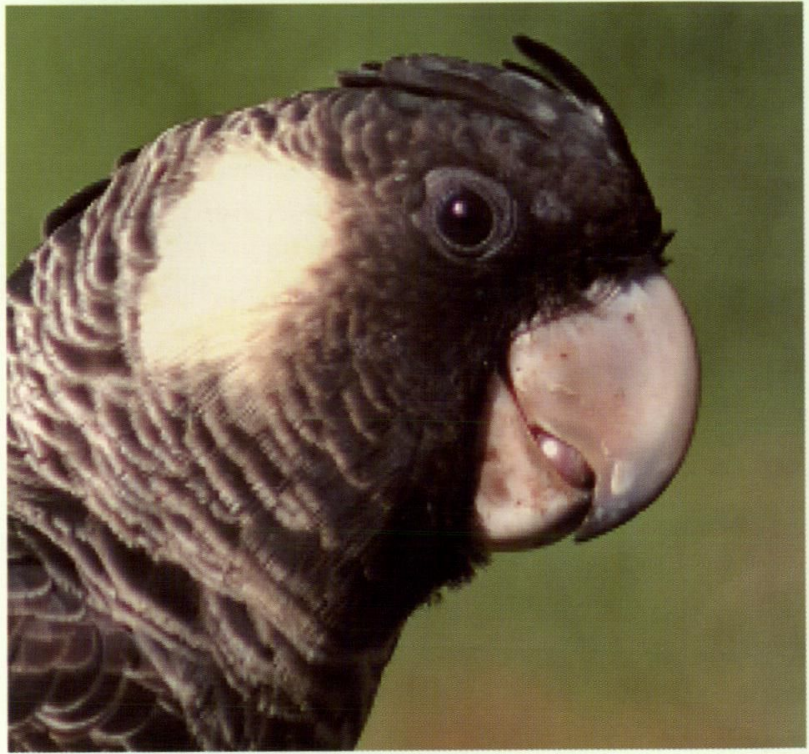

Female Carnaby's Cockatoo

Figure 1 Bill shape of Baudin's Cockatoo Calyptorhynchus baudinii (top) and Carnaby's Cockatoo Calyptorhynchus latirostris (bottom).

exotic species all exacerbate the future conservation of Baudin's Cockatoo in the south-west region. Recent studies (Johnstone and Kirkby 2007) have revealed the devastating impact feral honeybees are having on cockatoos and other hollow-nesting birds in this region.

While there has been a considerable amount of study carried out on Carnaby's Cockatoo since the 1960s (e.g. Saunders 1974, 1980, 1990), very few studies have been conducted on the forestinhabiting Baudin's Cockatoo. Baudin's Cockatoo is listed as Threatened (Endangered) under Schedule 1 of the Western Australian Wildlife Conservation Act 1950, and as Vulnerable under the Commonwealth Environment Protection and Biodiversity Conservation Act 1999. Although listed as an endangered species, it is also a declared pest of agriculture because it damages commercial fruits, especially apples and pears (Chapman 2007).

Over the past six years we have carried out extensive fieldwork throughout the south-west corner of Western Australia and the distribution, status, habitat requirements, feeding ecology, migration and movements, and details of roost sites and behaviour of Baudin's Cockatoo have been more clearly defined.

\section{METHODS}

From 2001 to 2007 we carried out field investigations throughout the south-west of Western Australia covering the entire range of Baudin's Cockatoo. Birds were located by stopping 
at regular intervals to listen for calls and search for signs of feeding activity such as chewed nuts and evidence of grubbing for insects (including torn-off bark and grublines on tree trunks). Birds were also recorded opportunistically. We also recorded the number and activities of all birds sighted, i.e. feeding, flight direction and breeding calls. The locality of all sightings was made with a GPS unit and the date, time of day and habitat details were also noted (including forest type, e.g. Karri (Eucalyptus diversicolor), Jarrah (Eucalyptus marginata) / Marri (Corymbia calophylla), Wandoo (E. wandoo) and Banksia woodlands). Flock sizes recorded within two hours after first daylight and before dusk were compared with flock sizes recorded at other times of the day using a Wilcoxon Rank Sums Test because the data did not meet the assumptions of a parametric test.

Other sources of historical and contemporary information on Baudin's Cockatoo were also extracted from the Storr-Johnstone Bird Data Bank, from specimens held in the Western Australian Museum and observations from the Cockatoo Care program (a joint initiative of the Water Corporation and the Western Australian Museum).

A number of roost sites used during the autumn-winter non-breeding season were located and monitored including roosts at Gidgegannup, Chidlow, Parkerville, Mundaring, The Lakes, Mahogany Creek, Kalamunda, Pickering Brook, Kelmscott, Roleystone (Araluen), Bedfordale (Wungong Dam), Gleneagle, Byford, Mundijong, Jarrahdale, Sullivan Rock, Serpentine Hills, Pipehead Dam, North Dandalup, Bannister, Lesley, Karragullen, Dwellingup, Crossman and Collie. Most roost sites were located by following the birds returning to the roost in the evening or by listening for the calls of large numbers of birds at dawn on windless mornings when their highpitched calls travel greater distances. Birds were counted at roosts by locating a good position in the flight-path, e.g., on a road, track or open area that birds will cross, preferably with an open skyline. Counts were made at dawn and dusk which involved recording, where possible, the pairs, family groups and small flocks as they departed or returned. Some counts were considered accurate to within a few birds when they returned to roost in small family groups and others were estimates if birds departed or returned en masse. The presence of Carnaby's Cockatoos at some of these roosts was taken into consideration when estimating totals, especially at some of the larger roosts such as Wungong and Araluen, where at times up to 200 Carnaby's Cockatoos were present. We used photographs at a number of sites to obtain accurate counts of individuals.

At the Wungong roost we also noted details of roost trees including species, height (measured with a Suunto clinometer), diameter at breast height $(\mathrm{DBH})$ and the distance between trees.

In 2005-2006 detailed observations were made of the relationship between the birds of two roost sites eight kilometres apart in the Canning (Araluen) and Wungong valleys. Notes on food, daily foraging distance and overlap of foraging ranges for the two flocks were recorded. Observations of flock movements and diet changes coincident with the seasonal ripening of some fruits (e.g. apples, pears, and persimmons) and the nutting cycle of the Marri were also made.

\section{RESULTS AND DISCUSSION}

\section{Distribution}

Figure 2 shows the distribution of Baudin's Cockatoo based on our observations and reliable historic records. This cockatoo is confined to the south-western humid and subhumid zones (areas with average rainfall of $600 \mathrm{~mm}$ or more). It ranges north to Gidgegannup and Hoddy Well and east to Clackline, Wundowie, the lower Darkin River, Boyagin Rock, Wandering, Williams, Kojonup and the King River also west to the eastern strip of the Swan Coastal Plain including West Midland, Armadale, Byford, Mundijong, Serpentine, North Dandalup and further west to the coast at Lake Clifton, Australind, Bunbury, Busselton, Dunsborough, Leeuwin-Naturaliste National Park and Augusta, also the Stirling and Porongurup Ranges and east along the south coast to Waychinicup National Park.

\section{Status}

Depending on their region of origin, Baudin's Cockatoo is a resident, a postnuptial nomad and migrant, with the bulk of the population largely vacating the coldest parts of their range (i.e. the Karri forest block) in the autumn and migrating northwards or with a strong tendency to wander from the interior towards the coast, but also in a few places resident in small numbers (e.g. Manjimup and the Leeuwin-Naturaliste ridge). Migrations and movements including visits between March and September from the deep south-west to the central and northern Darling Range (e.g. Collie, Samson Brook, Crossman, Bannister, North Dandalup hills area, SerpentineJarrahdale area, Wungong Valley, Araluen, Mundaring, Chidlow) and adjacent far east of the Swan Coastal Plain (e.g. Maida Vale, Kelmscott, Armadale, Byford, Mundijong, Serpentine, North Dandalup and further west to Lake Clifton, Bunbury, Capel, Busselton and Dunsborough). Baudin's Cockatoo is gregarious and is usually seen in family groups and small flocks. 


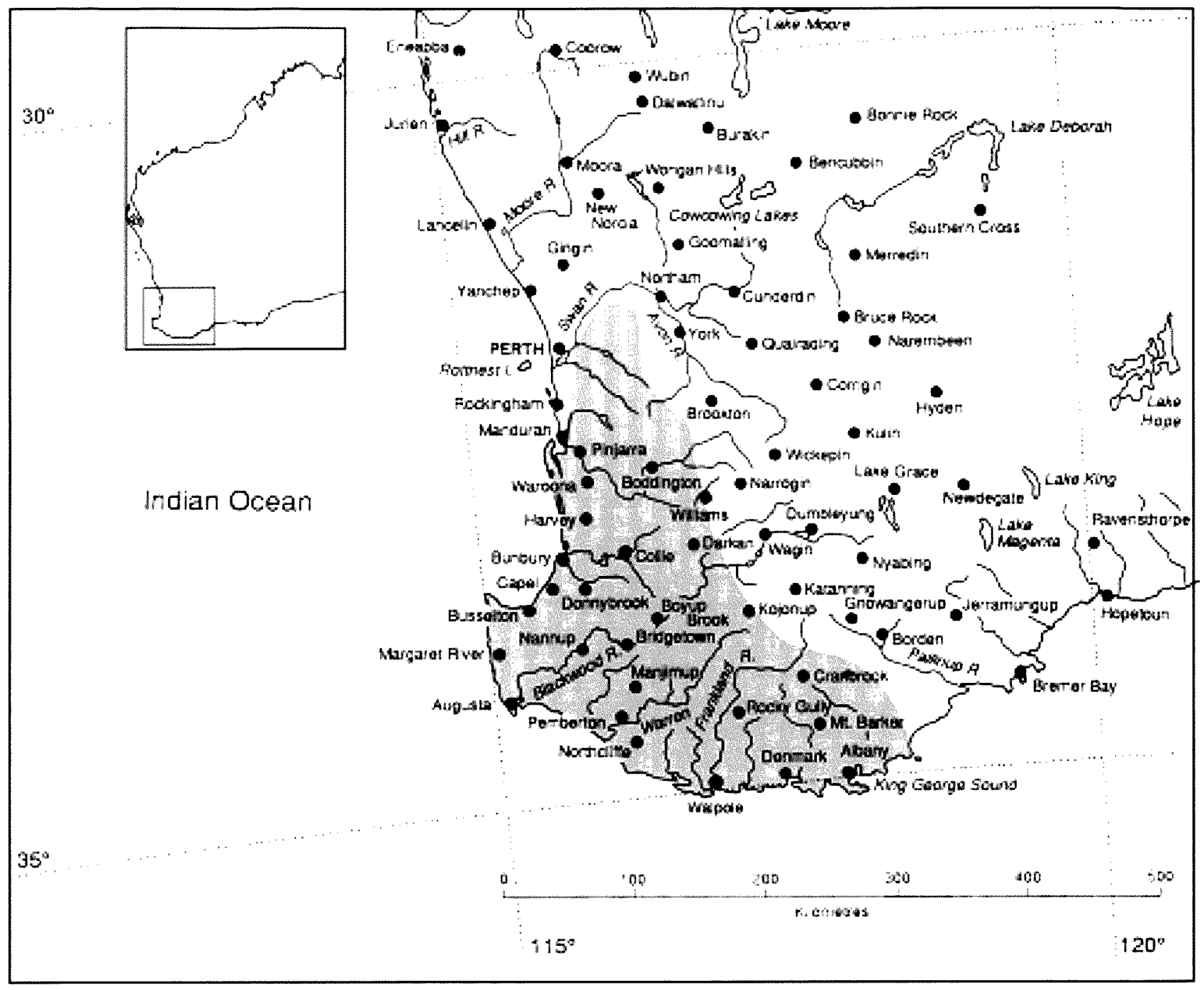

Figure 2 Distribution map of Baudin's Cockatoo Calyptorhynchus baudinii.

Baudin's Cockatoo's relative abundance ranges from scarce to moderately common: it is most numerous in the deep south-west during the spring breeding season, September-December and in the northern Darling Range during autumn AprilAugust. It is usually observed in small flocks (up to 30 ) occasionally in larger flocks (up to 50) or aggregations (up to 1,200) at drinking sites or roosts. Based on our recent surveys and roost counts, we estimate the total population to be 15,000 birds.

\section{Habitat}

Baudin's Cockatoo's are mainly found in eucalypt forests, especially Jarrah-Marri, also Karri forest, less frequently in woodlands of Wandoo, Blackbutt (Eucalyptus patens), Flooded Gum (Eucalyptus rudis), Yate (Eucalyptus cornuta), partly cleared farmlands and urban areas including roadside trees and house gardens. This cockatoo forages at all levels of the forest from the canopy to the ground, often feeding in the understorey on proteaceous trees and shrubs, especially Banksia, and in orchards both in trees and on dropped or fallen fruit on the ground.

\section{Breeding}

There is very little breeding information and the breeding biology of this species remains poorlyknown. We have recorded breeding in deep southwest, north to the Whicher Range and Lowden and also an isolated record at Serpentine (hills area) and east to Kojonup and near Albany. They nest in large, mostly vertical, hollows of Karri, Marri and Wandoo. Baudin's Cockatoos display strong pair bonds, are monogamous and probably mate for life. The pair stay together all year round except when the female is incubating and brooding. Both adults play a part in selecting the nest hollow, but only the female is responsible for renovation and preparing the hollow for breeding. Preparation of the hollow consisted of chewing around the entrance of the hollow and down one part of the interior wall. Males have been recorded making the breeding call 


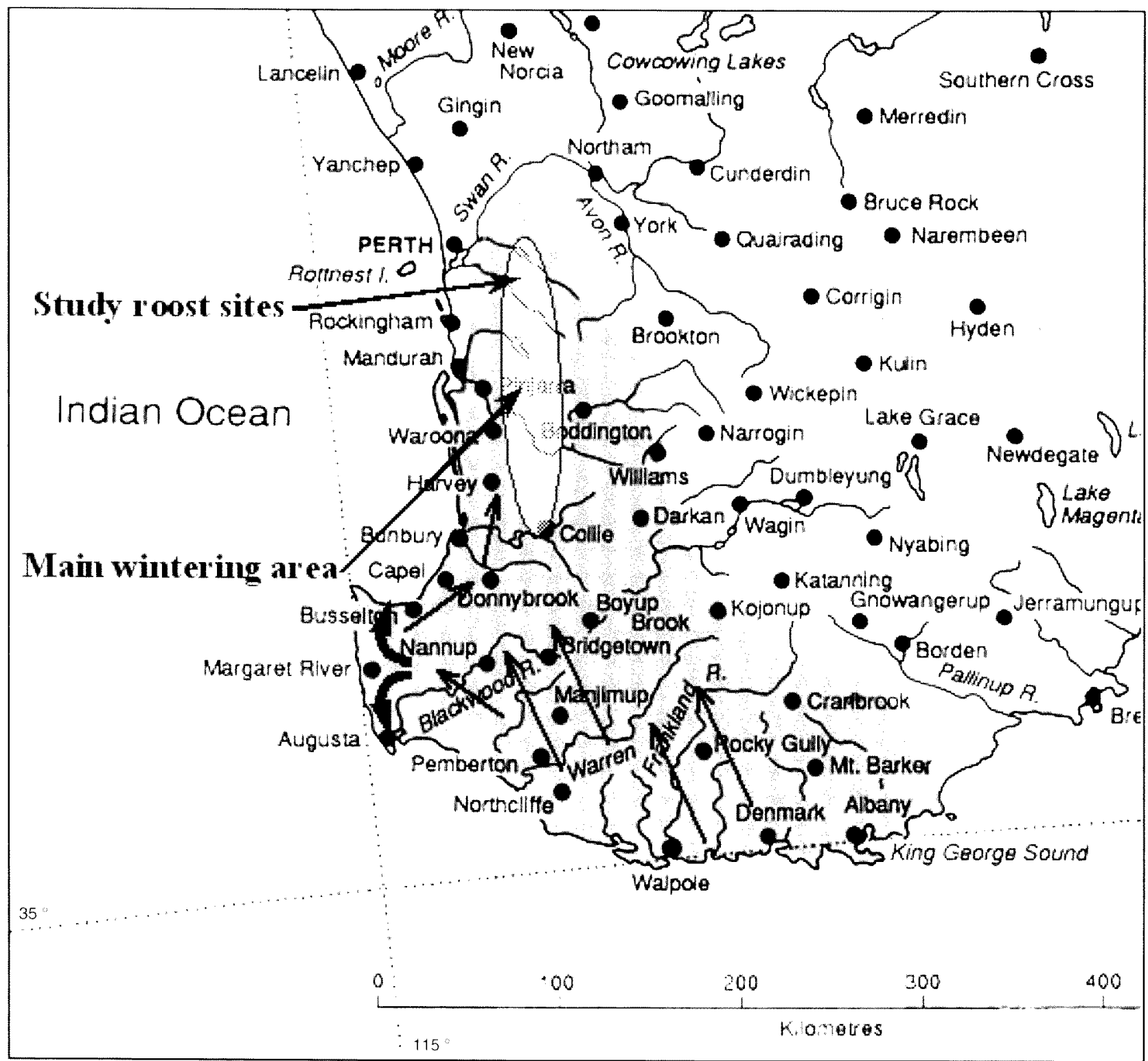

Figure 3 Map of south-west Western Australia showing migration and movements of Baudin's Cockatoo, main wintering range and Araluen and Wungong study roost sites (see Figure 6).

and displaying to females in most months, but this behaviour is more frequent in August, September and October. Pairs have also been recorded prospecting for hollows in most months and also outside the breeding range. Egg laying is recorded in August, September, October, November and December. The clutch size is 1-2, incubation lasts for about 29 days and only the female incubates and broods.

\section{Social organisation, flocking and movements}

Following breeding the birds leave the nesting areas and family groups then amalgamate to form larger foraging flocks. The flocks begin to arrive at non-breeding traditional roosts in the central and northern parts of the Darling Scarp (from about Collie north to Mundaring) in early February and
March. The largest groups $(>600)$ were recorded between April and September with some foraging out onto the southern Swan Coastal Plain to areas such as Kelmscott, Mundijong, Serpentine, Pinjarra, Harvey, Myalup, Bunbury, Capel, Tutunup, Busselton, Dunsborough and Meelup. Judging from our recent surveys for the groups of birds that have spent the non-breeding season in the Perth hills districts, there appears to be a definite shift westward onto the southern Swan Coastal Plain, just prior to the flocks moving south to breed.

This shift begins in mid-August and flocks of up to 200 birds have been recorded in AugustSeptember, at Armadale, Byford, Mundijong, Keysbrook, Serpentine, North Dandalup, Waroona and Yarloop. At this time some of the groups also formed roost sites at the western edge of the scarp 


\section{Baudin's Monthly Counts}

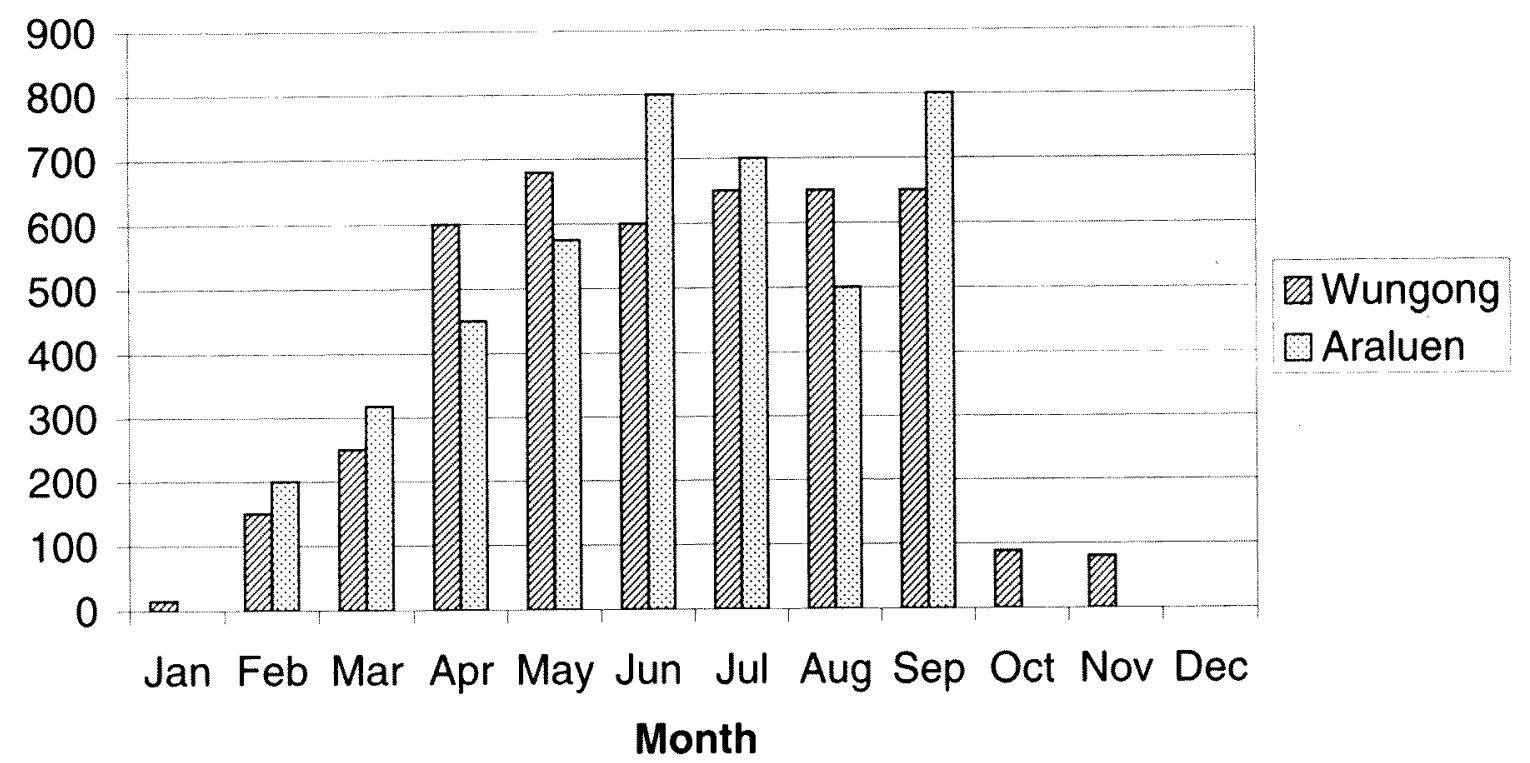

Figure 4 Highest monthly counts of Baudin's Cockatoo at roost study sites for the past ten years.

(Kelmscott 2006-2007) or out onto the coastal plain (Mundijong 2006-2007).

By mid-October most birds are either back in their breeding quarters, or heading there, and in breeding condition. For example, in 2006 on 17 October a flock of over 200 was observed near Frankland feeding on Storksbill (Erodium spp.) and Marri seed. On 22 October several breeding pairs were observed near Walpole, with males feeding females and one female entering and remaining in a nest hollow. On the same day, 10-12 pairs with displaying males were recorded near Lake Muir. On 23 October a flock of over 300 (mostly in pairs and family groups) with many males giving the breeding call and displaying to females was observed near Bridgetown. Most of this latter flock left what appeared to be a resting site in tall Lemonscented Gums at about 09:30, and although some pairs remained in the vicinity a large loose aggregation (most of the flock) appeared to be still moving southwards. Also on 9 October, a flock of 250 was observed feeding on Storksbill on the Vasse Highway near Nannup and on 20 October a flock of 200 was observed $3 \mathrm{~km}$ south of Nannup feeding on Storksbill.

Also noteworthy is that two flocks were recorded near Williams, a flock of 16 flying south with males making the breeding call on 20 October 2004, and a flock of 21 was flying east on 17 October 2006. These records are of interest as Baudin's Cockatoo is generally not recorded in the Williams area and these birds were most likely migrating back to their breeding sites.

\section{Roost sites and daily routine}

A number of roost sites used by Baudin's Cockatoo during the winter non-breeding season have been located and some of these monitored for over ten years. Of these, the larger northern roosts seem to be used on a yearly basis including Gidgegannup, Piesse Brook, Nganguring, Mundaring (Weir Road), Araluen, Wungong, North Dandalup (Myara Road) and Serpentine. For example the Piesse Brook roost has been used every year for at least 21 years and the Wungong roost for at least the past 12 years. Other smaller roost sites up to $8 \mathrm{~km}$ away from the main roosts are also used on occasions, presumably when foraging distances from the main roost become too great. Most roost sites are in tall emergent eucalypts (especially smooth-barked exotic eucalypts) or Blackbutt (see Table 1), often near watercourses and in sheltered gullies. Trees used for roosting need to be a certain height, have a canopy with enough leaves to shield the cockatoos from the elements and possibly help them retain body heat. What makes cockatoos discriminate between suitable and unsuitable roost sites is of interest because some roosts have very different characteristics including geographic location, position in landscape, tree type, tree height, canopy density, surrounding vegetation and distance to drinking and foraging sites. The majority of roosts comprise a fairly large stand of tall trees, with a dense canopy and situated close to permanent water. The Wungong roost is one of the few roost sites in natural vegetation namely, Blackbutt (64 trees), Wandoo (18 trees), Flooded 
Table 1 Location of roost sites.

\begin{tabular}{|c|c|c|c|c|}
\hline \multicolumn{2}{|l|}{ Location } & \multirow{2}{*}{$\begin{array}{l}\text { Max } \\
\text { number } \\
\text { counted }\end{array}$} & \multirow{2}{*}{$\begin{array}{l}\text { Date } \\
\text { recorded } \\
\text { June } 2004\end{array}$} & \multirow{2}{*}{$\begin{array}{l}\text { Roost tree species } \\
\text { and site } \\
\text { Smooth-barked exotic cucalypts along } \\
\text { creekline. }\end{array}$} \\
\hline Waterford Road & Gidgegannup & & & \\
\hline Rosedale Road & Chidlow & 300 & June 2004 & $\begin{array}{l}\text { Smooth-barked exotic eucalypts along } \\
\text { creekline. }\end{array}$ \\
\hline Roland Road & Parkerville & 300 & June 2004 & Smooth-barked exotic eucalypts near creekline. \\
\hline Stoneville Road & Mundaring & 550 & June 2006 & $\begin{array}{l}\text { Smooth-barked exotic eucalypts. Flooded Gum } \\
\text { near creek. }\end{array}$ \\
\hline Nganguring Road & The Lakes & 370 & June 2006 & Wandoo \\
\hline Margaret Road & Mahogany Creek & 100 & June 2004 & Smooth-barked exotic eucalypts near creekline. \\
\hline Mundaring Weir Road & Mundaring & 450 & May 2003 & Smooth-barked exotic eucalypt near creekline. \\
\hline Aldersyde Road & Kalamunda & 315 & April 2006 & Flooded Gum along creekline \\
\hline Canning Road & Pickering Brook & 80 & July 2003 & Flooded Gum along creekline \\
\hline River Road & Kelmscott & 200 & September 2005 & $\begin{array}{l}\text { Smooth-barked exotic eucalypts. Flooded Gum } \\
\text { along river. }\end{array}$ \\
\hline $\begin{array}{l}\text { Lady McNess Drive, } \\
\text { Araluen }\end{array}$ & Roleystone & 800 & June 2006 & Smooth-barked exotic eucalypts near creekline. \\
\hline Albany Highway & Armadale & 200 & September 2003 & Smooth-barked exotic eucalypt near creekline. \\
\hline $\begin{array}{l}\text { Admiral Road, } \\
\text { Wungong }\end{array}$ & Bedfordale & 680 & August 1998 & $\begin{array}{l}\text { Blackbutt, Flooded Gum, Wandoo, Marri along } \\
\text { creekline. }\end{array}$ \\
\hline North Todd Road & Gleneagle & 250 & July 2005 & Blackbutt along creekline. \\
\hline Todd Road & Gleneagle & 400 & May 2004 & Blackbutt along creekline. \\
\hline South Todd Road & Gleneagle & 300 & May 2004 & Blackbutt along creekline. \\
\hline Admiral Road & Byford & 30 & May 2006 & Smooth-barked exotic eucalypt \\
\hline Kiernan Street & Mundijong & 190 & October 2006 & Smooth-barked exotic eucalypts near creekline. \\
\hline Jarrahdale Road & Jarrahdale & 200 & August 2004 & Blackbutt along creekline \\
\hline Gooralong & Jarrahdale & 200 & March 2007 & Blackbutt along creekline \\
\hline Millars Log Road & Sullivan Rock & 120 & August 2003 & Plantation. Smooth-barked eucalypts \\
\hline Scarp Road & Serpentine Hills & 184 & May 2006 & Bullich along creekline \\
\hline Scarp Road & Pipehead Dam & 450 & May 2004 & Flooded Gum along creekline \\
\hline Myara Road & North Dandalup & 400 & August 2005 & Bullich along creekline \\
\hline Bannister Hill & Bannister & 200 & August 2006 & Wandoo near creekline \\
\hline Brookton Highway & Lesley & 150 & December 2004 & Plantation. Smooth-barked eucalypts \\
\hline Canning Road & Karragullen & 50 & September 2004 & Plantation. Smooth-barked eucalypts. \\
\hline Nanga Road & Dwellingup & 40 & August 2006 & Flooded Gum \\
\hline Hotham River & Crossman & 150 & October 2003 & Flooded Gum along river \\
\hline Crossman Road & Crossman & 300 & July 2003 & Flooded Gum \\
\hline Lyalls Mill & Collie area & 110 & August 2006 & $\begin{array}{l}\text { Plantation. Smooth-barked eucalypts along } \\
\text { creekline. }\end{array}$ \\
\hline
\end{tabular}

Gum (5 trees), and Marri (5 trees), a total of 92 trees. The trees range in height from 14-29 $\mathrm{m}$ (average $20.38 \mathrm{~m}$ ) and of the 92 trees, 26 are heavily used and are concentrated in the centre of the roost and as numbers of birds increase the other 66 trees in the outer sections of the roost become occupied. The largest flocks recorded at roost sites in the nonbreeding season include 800 at Araluen on 18 June 2006 and 680 at Wungong on 27 August 1998 (Table $1)$.

The daily routine of birds at the Araluen roost in Canning Valley and Wungong roost in Wungong Valley have been studied in detail for the past ten years. The Araluen roost is in smooth-barked exotic eucalypts along a creek and the Wungong roost is in mainly Blackbutt and Wandoo (Figure 5) at the edge of a creek. Both roosts are in valleys that provide some protection from prevailing weather.
This is often needed as the birds roost as individuals (about $30 \mathrm{~cm}$ or more apart) in the outermost thin branches of the canopy, often among a clump of dense leaves, and generally in situations that would appear to be affected by strong winds.

It is noteworthy that Carnaby's Cockatoo also roosts in a similar fashion to Baudin's Cockatoo which is very different to that of Red-tailed Black Cockatoos (Calyptorhynchus banksii naso) that roost side-by-side in family groups and on thick, protected perches under the canopy of tall trees.

Birds begin calling from the roost well before sunrise, e.g. birds were calling as early as 06:00 hrs when dawn-twilight was at 06:12 and sunrise was 06:36. The earliest calls of the day are the begging calls of juveniles and immatures. Usually just after dawn-twilight period, any small groups that roost away from the main flock come into the main roost 

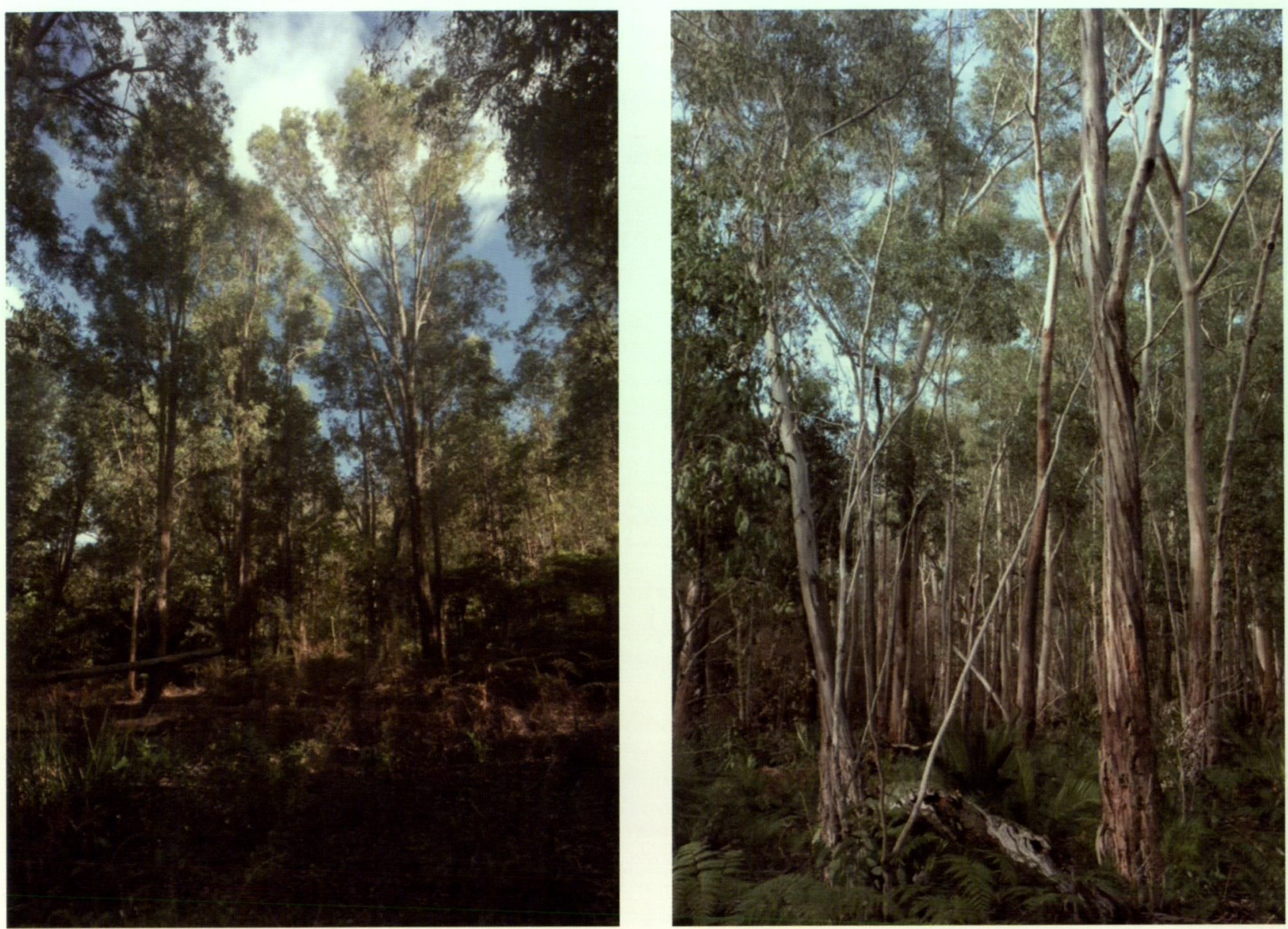

Figure 5 Wungong roost site (Blackbutt). Myara Road roost site (Bullich).

area to join the others and call frequently. After departing the main roost, the birds in the Araluen group usually congregate in dead trees along the adjacent Croyden Road in what we term pre- or post-roost sites. These sites are either in dead trees or dead limbs of live trees that project beyond the canopy of the surrounding forest. Although there is suitable feeding habitat (including stands of Marri trees that the birds could presumably forage in near the Araluen roost), this flock rarely remains near the roost for more than one hour. In contrast, the Wungong flock sometimes remains in the valley feeding until mid-morning. As an example, in one day's foraging in May along the Wungong Valley (west of the roost), the flock of ca 450 left the roost at 06:55 hrs and by 08:05 had moved a distance of $3.5 \mathrm{~km}$ which was the limit from the roost that day. While moving west the flock had short stops along the way to preen, socialise and forage on grubs and seeds from Marri and the seeds of Dryandra praemorsa. Many remained at these feeding areas and the total flock size at the site $3.5 \mathrm{~km}$ from the roost was reduced to about 250 birds.

Sometimes this group also feeds in and around the Persimmon orchards along the Albany Highway, Bedfordale $(3.2 \mathrm{~km}$ north of roost). At these times they also take approximately one hour to cover this distance, feeding, preening and socialising along the way. It is unusual for this group to be recorded more than $4.5 \mathrm{~km}$ from the roost site. When foraging to the east in June 2004 and May 2005 this flock formed a 'new roost' (roost 2) in Blackbutt along the valley of 31 Mile Brook. From this roost, the group was then observed to leave at dawn and forage along a path, taking them still further east. This group later formed two other roosts further south along the valley. The greatest distance this flock moved before forming a 'new roost' was $5 \mathrm{~km}$. After forming these roosts in 2004, only half of the group later returned to the main roost in Wungong Valley before departing to breed; in 2005 all had returned within a month.

At times, the flock from the Araluen roost feed on apples in the orchards in the Karragullen area. The orchards are $4.5 \mathrm{~km}$ north of the roost and the first birds fly mainly over Jarrah/Marri forest and arrive between 30-60 minutes after dawn. For example, a flock of 600 birds arrived to feed on rotting apples in the orchards along Elizabeth Street, Karragullen at 07:40 (dawn 06:49) in May 2006. The first birds of a flock of 460 arrived at 07:50 (dawn 06:49) in July 2007. Sixty birds from the Araluen roost were recorded feeding on Marri seeds along Canning Road $7.7 \mathrm{~km}$ from the roost in July 2005, two hours 


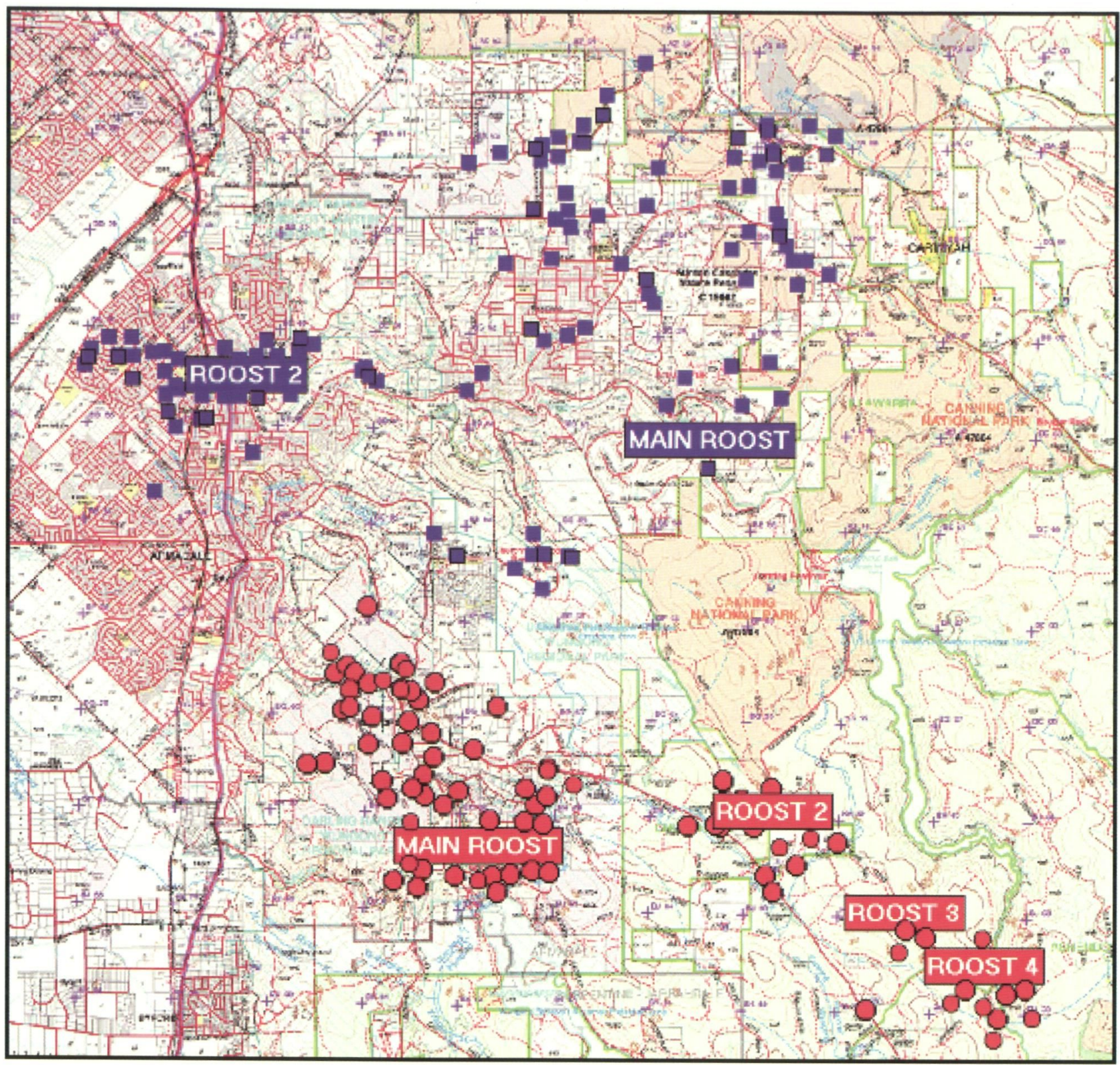

Figure 6 Sightings of Baudin's Cockatoos from Araluen Roost ( $\square$ ) and Wungong Roost ( $)$.

after dawn. A small roost (ca. 40 birds) located in plantation timber in this area may be a satellite roost formed by these Araluen birds. The Araluen group also formed a roost of ca. 200 birds in very tall smooth-barked exotic eucalypts along River Road, Kelmscott in late August 2005. This roost is 8 $\mathrm{km}$ from the main roost and from here the group foraged out onto the coastal plain in the suburbs up to a distance of ca. $3 \mathrm{~km}$ feeding mainly on Marri seeds and nectar from Callistemon spp.

Away from roost sites, the largest groups recorded are usually within the first two hours of daylight, or in the two hours before dusk, as flocks commonly break into smaller family groups then aggregate into larger flocks later in the day, approximately two hours before dusk, when returning to roost sites. It was found that the size of groups and individuals recorded (away from roost sites) during these periods were almost double that for the rest of the day.

Average group size in the two hours after dawn combined with the two hours before dusk was 64.5 (Std error $=3.9, n=716$ observations) and for the rest of the day the average was 33.9 (Std error $=2.6$, $n=400$ ). Flock sizes within two hours of dawn and dusk varied significantly from flock sizes at other times of the day $(z=-4.31$, d.f. $=1,1115, \mathrm{P}<0.0001)$. The largest count at the dawn and dusk period was 1200 birds with 29 counts of flocks over 350. The largest flock recorded outside this period was 350 with only 13 counts of flock sizes of 200 or larger.

Throughout most of the day there are some birds in the flock feeding, however, there are also obvious periods of loafing, bill cleaning, preening, allopreening and socialising. During this period most of the juveniles begin to solicit food from 
parents at the same time, begging persistently. Most feeding of juveniles occurs between dawn and midday and again later in the afternoon near roosting times. When feeding the chick, the parent bird begins by head bobbing with the juvenile crouched or positioned on the branch lower than the adult, then with bills interlocked (i.e. heads tilted in opposite directions) the heads are pumped up and down and the food transfer occurs.

The birds at Karragullen have been observed returning to the roost at Araluen $4 \mathrm{~km}$ away between 25 and 90 minutes before sunset. Most birds stop to feed on Marri seed along the return journey and rarely arrive at the roost site until almost dark. One flock of 200 was noted travelling $1.5 \mathrm{~km}$ in 25 minutes, with groups 'leapfrogging' and feeding on Marri seed as they headed back to the roost. There is no strict routine with birds sometimes flying into the roost in small family groups and at other times in loose aggregations up to 200.

The Wungong flock sometimes remains in the Wungong Valley near the roost site for up to two and $a$ half hours before moving any distance. On other occasions they will leave the roost area and valley before dawn. At dawn on some mornings, small flocks fly slowly up the valley, stopping to feed on Marri seed and, on other mornings, the entire flock erupts from the roost leaving en masse within a few minutes. This behaviour occurs at all roosts. On three occasions a Wedge-tailed Eagle (Aquila audax) has been sighted at dawn near the roost site at Wungong, the entire flock of birds then rise as a tight group and circle, climbing higher and higher until the eagle had passed. Although foraging birds may return to the same trees to feed, they usually do not feed in the same tree for long periods. For example on 7 August 2007, 12 birds were observed searching for grubs in a dead Marri along a track in the Wungong area where they fed for approximately 30 minutes before moving further into the forest. A short time later another group of 15 birds moved into the same tree and commenced grubbing. Birds may also leave the roost and forage in one direction for a few days before heading off in another direction a day or so later. It is noted that this Wungong group, and the Araluen group, very rarely move south from the roosts to forage in forested areas in the Canning and Wungong catchments. The foraging range of the Araluen flock (up to 800 birds) includes Jarrah/ Marri forest, road verges, reserves, orchards and suburban gardens covering an area of ca $70 \mathrm{~km}^{2}$.

Birds often congregate to drink at habitual sites before moving to the roost area. We have recorded Baudin's Cockatoos drinking from large catchment dams, farm dams, troughs, open creeks in paddocks, well vegetated and overgrown creeks in forests, roadside pools and pools on gravel tracks, water in tree hollows, claypans, swampy paddocks, granite outcrops, garden fountains and ponds. Drinking has been observed at various times throughout the day, but most records are from birds leaving or returning to roost sites.

Although the vast majority of birds at these nonbreeding roost sites leave and return to the roost sites together and in the same direction (i.e. head north at dawn and return from the north at dusk), small groups are sometimes noted leaving and returning in other directions. At times the flock from Piesse Brook will forage in a generally southern direction but small groups also forage to the west towards Kalamunda. This seems typical of most groups.

Although it seems improbable that the foraging ranges of these winter groups do not overlap, from 53 roost counts the group from Araluen has only been recorded heading to or from the direction of the Wungong roost (south) on one occasion. In fact the opposite is the case with the group usually heading generally north while the direction of the Wungong roost is south. However, in August 2003, a group of 110 birds and, in May 2004, a group of up to 150 birds known to originate from the Araluen roost were foraging in the Churchmans Brook area. This is approximately midway between the Araluen and the Wungong roosts and birds from the Wungong area have been known to forage within one kilometre of this site. If birds do move between these winter roosts then it is at best infrequent and irregular. It is also noted that the group from the Carmel roost have for the past two non-breeding seasons been recorded feeding on the seeds of Jacaranda. This introduced tree species is common within the foraging ranges of most of the winter roost sites of Baudin's Cockatoo north of Serpentine Hills yet this trait hasn't yet been recorded elsewhere. If these birds move between roosts or are in regular contact then it would seem reasonable to assume that this food source would have been exploited in other areas.

\section{Flock composition}

Counts made as birds returned to a roost site could sometimes be broken down into smaller family groups. From these counts we can gather limited data as to the composition of these nonbreeding populations e.g. ratios of immatures/ juveniles in the total flock. Only counts as birds returned to roosts were used, as at other times, particularly in forested areas, breaking the groups into family units was considered inaccurate.

From a total of 3,899 individuals we were able to count the following family groups: single birds 100 , groups of two -482 , groups of three -519 , groups of four -182 and groups of five -110 .

The only groups that can be defined with reasonable certainty are the family groups of three 
and four. Groups of three are male, female and juvenile/immature and groups of four are male, female, juvenile and what appears to be an immature from a previous breeding. Whatever the status of this fourth bird, it is almost certainly a non-breeder. Groups of five also contain an immature/juvenile bird. Single birds were probably birds separated from a mate or family group and made up only $2.5 \%$ of the total number of individuals counted. Pairs of birds could not be reliably counted as adult breeding pairs, as a proportion of these are assumed to be sub-adults that have paired off but have not yet bred, and some are probably older birds that are no longer breeding. From these figures, the minimum number of non-breeding immatures/juveniles in the total counts was 993 or $25.5 \%$. Most of these counts were from the Wungong roost (1,644 individuals) and the Araluen roost ( 830 individuals). The minimum percentage of non-breeding birds from these roosts was $27 \%$ and $24 \%$ respectively. The minimum number of adult breeding birds was 1,622 or $41.5 \%$. The minimum number of adult breeding birds from the Wungong (total number) and Araluen (total number) flocks was $740(45 \%)$ and $315(38.5 \%)$ respectively.

\section{Food}

Baudin's Cockatoo has been observed feeding on a wide range of foods including the seeds of Corymbia calophylla, Eucalyptus marginata, Allocasuarina fraseriana, Banksia grandis, $B$. quercifolia, B. littoralis, B. ilicifolia, Hakea erinacea, $H$. prostrata, $H$. stenocarpa, $H$. trifurcata, $H$. lasianthoides, $H$. ruscifolia, $H$. lissocarpha, $H$. varia, H. cristata, H. marginata, Dryandra sessilis, D. squarrosa, D. praemorsa, Grevillea wilsonii, Xanthorrhoea preissii, Kingia australis, Reedia spathacea, Pinus radiata, Erodium spp. (including E. botrys), Jacaranda spp., Macadamia spp., Pecan Carya illinoinensis, Apples Malus spp., Pears Pyrus spp., Persimmons Diospyros spp. and Quercus spp.; nectar, buds and flowers of Corymbia calophylla, C. citriodora, Eucalyptus marginata, E. wandoo, Eucalyptus spp., Banksia grandis, Dryandra sessilis, D. lindleyana, $D$. squarrosa, Darwinia citriodora and Callistemon spp. They also take insect larvae and insects (including beetle, wasp and moth larvae) from under bark and in wood of live and dead trees, from galls and from flower spikes of Xanthorrhoed; the pith of Anigozanthos flavidus. The juice of ripe persimmons and the growing tips of Pinus spp. Overall Marri Corymbia calophylla is the primary food source with the birds using its seeds, flowers, nectar and buds. Also it appears that in years when the Marri fails to flower or flowers poorly are the years when damage by this cockatoo to cultivated fruits is most severe.

\section{Conservation}

The long-term survival of Baudin's Cockatoo is of increasing concern. Previously a very robust population, it appears to have declined greatly in the past 50 years (Johnstone and Storr 1998). Its low rate of reproduction (0.6 chick per year or every two years) precludes it from replacing the large numbers shot by orchardists and those lost through other causes such as habitat destruction. Over a quarter of its original habitat has been cleared. The future conservation of this forest cockatoo provides us with an immediate challenge in reducing its major threats, namely illegal shooting by orchardists, deaths caused by road strikes, loss of feeding and breeding habitat and the impact of nest competitors including the feral European honey bee. The current view is that as a result of these threats, this species is declining and threatened with extinction (DEC 2008) gives some urgency to the development of recovery and management plans. It is also crucial that research into its breeding biology, including migration and movements, threatening processes, food requirements and the size and health of breeding populations are undertaken.

\section{Conclusions}

Despite Baudin's Cockatoo being a large iconic forest cockatoo we still know very little about its breeding biology such as its breeding range, timing of nesting events, nest tree and nest hollow characteristics, clutch size, incubation period, fledging period and nesting success. Furthermore, there is an urgent need to clarify the habitat requirements and movements of both Baudin's and Carnaby's Cockatoos in many parts of the southwest. The movements of both of these cockatoos are no doubt dictated by food availability as controlled by climatic effects on habitat, and if this is the case, how do these birds co-ordinate their migrations accordingly? Judging from the historical data, there have been enormous changes in the distribution and status of both of these cockatoos in the past 50 years. As the climate warms in the south-west, species that currently undergo extensive movements may either shorten their migration distance or even stop migrating and remain year round in certain rainfall zones. With a decrease in rainfall (which has occurred over the past 30 years), Baudin's Cockatoo could be expected to contract towards high rainfall zones in the south-west. On the other hand, we would expect the more-arid adapted Carnaby's Cockatoo to be contracting or extending its breeding range westwards and southwards and this shift appears to be happening (unpublished data).

Further GIS study of roost sites would be valuable. Baudin's Cockatoos appear to have set foraging patterns that change based on the 
availability and seasonality of resources and can range daily over about $6 \mathrm{~km}$. Mapping the available resources within a $10 \mathrm{~km}$ radius and how far some of these flocks range to find food could have useful applications especially in areas with a mosaic of forest, agriculture (fruit growing) and urban landscapes. Further studies are now also required to determine the breeding distribution and to map and monitor important breeding, feeding and roosting sites throughout the south-west.

\section{ACKNOWLEDGEMENTS}

It is a pleasure to express thanks to the Water Corporation for their financial support and allowing us access into their catchment areas. We are also grateful to Kim Sarti and Tamra Chapman for help with the preparation of this paper. Many thanks to Carol Kirkby for help in counting birds from the Wungong, Araluen and Myara Road roosts and also Ken and Glenny Caratti for providing valuable roost data and access to the roost on their property.

\section{REFERENCES}

Campbell, N.A. and Saunders, D.A. (1976). Morphological variation in the white-tailed black cockatoo, Calyptorhynchus baudinii, in Western Australia: a multivariate approach. Australian Journal of Zoology 24: 589-595.

Chapman, T.F. (2007). An endangered species that is also a pest: a case study of Baudin's Cockatoo Calyptorhynchus baudinii and the pome fruit industry in south-west Western Australia. Journal of the Royal Society of Western Australia 90: 33-40.
DEC (2008). Forest Black Cockatoo (Baudin's Cockatoo Calyptorhynchus baudinii and Forest Red-tailed Black Cockatoo Calyptorhynchus banksii naso) recovery plan 2007-2016. Wildlife Management Program No. 42. Department of Conservation and Land Management: Perth, WA.

Johnstone, R.E. and Storr, G.M. (1998). Handbook of Western Australian Birds, Volume 1 Non-Passerines (Emu to Dollarbird), Western Australian Museum: Perth, WA.

Johnstone, R.E., Kirkby, T., Stone, P. and Minton, C. (2005). White-tailed Black-Cockatoos: Identification challenges and changes in distribution and status, and links with a community program - Cockatoo Care (pp. 32-35). In: Gole, C. (ed), Carnaby's Black Cockatoo: Future Directions Symposium. Birds Australia, Western Australia: Perth, WA.

Johnstone, R.E. and Kirkby, T. (2007). Feral European honeybees: a major threat to cockatoos and other tree hollow users. Western Australian Naturalist 25: 187190.

Long, J.L. (1985). Damage to cultivated fruit by parrots in the south of Western Australia. Australian Wildlife Research 12: 75-80.

Saunders, D.A. (1974). Subspeciation in the white-tailed black cockatoo, Calyptorhynchus baudinii, in Western Australia. Australian Wildlife Research 1: 55-69.

Saunders, D.A. (1979). Distribution and taxonomy of the white-tailed and yellow tailed black cockatoos Calyptorhynchus spp. Emu 79: 215-227.

Saunders, D.A. (1980). Food and movements of the shortbilled form of the White-tailed Black Cockatoo. Australian Wildlife Research 7: 257-269.

Manuscript received 30 October 2007; accepted 23 May 2008. 


\title{
Guide to Authors
}

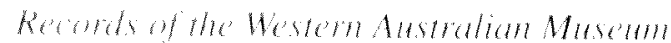

\section{Subject Matter}

Original revearch revexs and oberations in all banches of natural science and homan studies will be considered for publication. However, emphasis is placedon studies pertaming to Western Australia and neighboring regions. I onger papers will be considered for publication as Supplements to the Records of the Westem Australion Musenm. Such publications may attract charges to the authers to ofted the coss of printing - athors should consult the editors before submitting large manuscripts. Shont communications should not nomally exceed three typed pages and this category of paper is intended to accommodate observations, results or new records of significance. All material must be original and not have been published elsewhere

\section{Presentation}

Authors are advised to follow the layout and style in the most recent issue of the Records of the Western Australian Masem including headings, tables. illustrations and references. When in doubt use a simple fomat that is easily edited. Please provide line numbers throughout the MS (e.g.. in Word go to File Page Setup Layour (tab) line Numbers (button), add line numbers and click on "continuous" numbering).

The title should be concise, informative and contain hey words necessary for retrieval by modern searching lechmiques An abridged title (not exceeding 50 character spaces) should be included for use as a running head.

An abstract must be given in full length papers but not whot communications. summarizing the scope of the work and principal findings. It should normally not exced $2 \%$ of the paper and be suitable for reprinting in reference periodicals At the end of the abstract, provide several keywords not already included in the ritle

The International System of units should be used. Spelling should follow the Concise Oxfond Dic fionary. Numbers should be spelled out from one to nine in descriplive text: figures used for 10 or more. For associated groups, figures should be used consistently (e.g. "s to 10 ", not "five to $10 "$ ).

Systematic papers must conform with the Internationat Codes of Botanical and Zoological Nomenclature and. als far as posible, with their recommendation.

Symomyes should be given in the shom fom taxom. atuhor date, page and the full reference cited at the end of the papes. All citations, including those associatled with ecientific names in taxonomic works. must be included in the references

\section{Manuscripts}

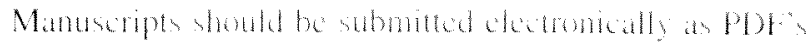

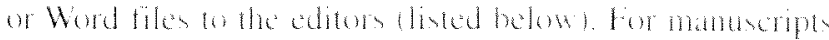
with large imase files submisuion of a CD is accoptable Manuseripts must be 1.5 or douhle spaced throughout and margins at leats 25 mm wide. On separate pages indude table (plus heading sand tecure legends. Table whold be numbered conscentively, have heading which mathe them undertandable

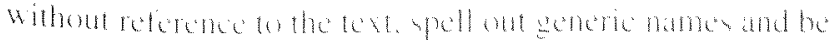
referrod to in the

\section{Figures}

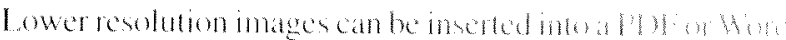

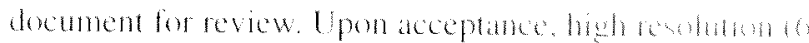
$10 \mathrm{Mb}$ ) images in TIf burned to CD and posted wo the editors. We preter lllt: How for figures. For Adobe Illustrator and Sigmaplot, sate in ope cencapsulated postseript) format: for Ponerpoint sate in. Whit twindows metafile format): for fxecl sate an fred of worksheet (must contain spreadsteet and enbeded hath: and for CorelDraw save as an eps file that maty be opened by Adobe Illustrator.

Scanned photographs should be saved at Thlt files. All TIFF files should be compatible with Adohe Photoshop. II figures are prepared in a paint program. for black and whe line art save at 600 dpi as a black and whice bimat mot greysate or colour), and greyscale and colour lime ant at 3 (n) Ipi.

Scale must be indicated on illustrations. Uhe amow of ohe aids to indicate specific features mentiond in the the th maps. line drawings photographs and graph whould be numbered in sequence and referred 10 as "Figure" ins

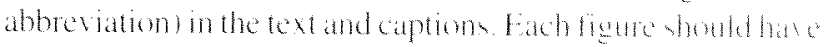
a brief fully explanatory caption.

\section{References}

In the body of the text. references should be cired an follows

Mckenzie and colleagues (Mckenzie 1999, 2000) McKenzic et al. 2000$)$ found that bat frequencies were highes on fill moons. contra previous workes (Smith and Jonce 1982: Berman 1988: Zuckeret al 1992)

All references must be cited in the text by anthor and dat and all must be listed atphabetically at the end of the papet The names of journals are to be given in full. Comstl atreen edition of the Records for style. For taxonomic papers. include full references for all taxonomic groups mentioned in the text In manuseripts dealing with historical subjects reterences ma be cited as foomotes.

\section{Processing}

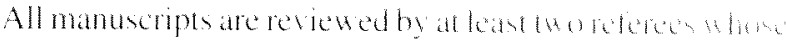
reports assist the editors in making their dectsin whether

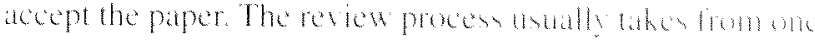

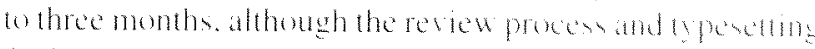
for longer manuscripts and supplements are watilly hones.

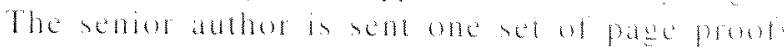
electronically which must be retumed withon one is ech after receipt.

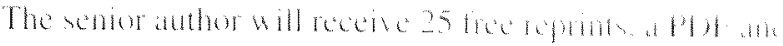

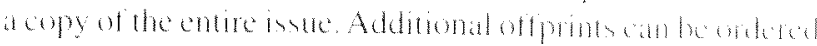
at page prest stage

\section{Editors}

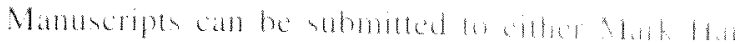

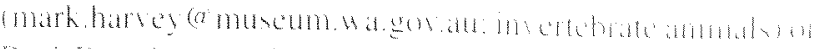

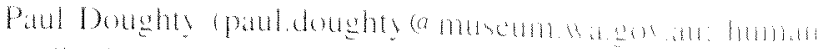

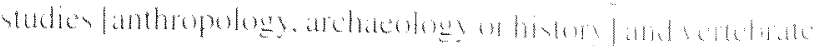
animaks. 


\section{Records of the Western Australian Museum Volume 25 Part 12008}

\section{CONTENTS}

John M. Huisman, Diana S. Jones, Fred E. Wells and Timothy Burton

Introduced marine biota in Western Australian waters

Volker W. Framenau and Melissa L. Thomas

Ants (Hymenoptera: Formicidae) of Christmas Island (Indian Ocean):

identification and distribution

Jim I. Mead, Marci Hollenshead, Sandra L. Swift, Christopher J. Bell and Alexander Baynes

Pygopus (Squamata: Pygopodidae) from mid-Holocene cave deposits, Western and South Australia

\section{P. Doughty and M. N. Hutchinson}

A new species of Lucasium (Squamata: Diplodactylidae) from the southern deserts of Western Australia and South Australia

\section{R.E. Johnstone and T. Kirkby}

Distribution, status, social organisation, movements and conservation of Baudin's Cockatoo (Calyptorhynchus baudinii) in South-west Western Australia

\section{Dates of Publication}

Records of the Western Australian Museum

Volume 24, Part 1

Volume 24, Part 2

Volume 24, Part 3

Volume 24, Part 4
23 October 2007

7 March 2008

24 July 2008

19 November 2008 